POLISH POLITICAL SCIENCE

VOL XXXVII 2008

PL ISSN 0208-7375

\title{
REVIEWS
}

\section{Book review: Jan Zielonka, Europe as an Empire. Fresh Glance at the European Union, The Polish Institute of International Affairs, Warsaw 2007, pp. 268}

\section{by Józef M. Fiszer}

Seemingly the European Union topic, globalisation and new international order issues have received enough attention, with scores of books published on the subject, innumerable conferences and seminars held, both in Poland as well as in countries all over the world, Western Europe in particular. Despite all that, many questions bothering academics and politicians remained unanswered, not to mention ordinary people in EU member states and countries aspiring to the Union membership. Still no one knows in what direction the changes should proceed, in relation to the European Union as well as the rest of the world, commonly referred to as globalisation or economic globalisation processes. We still do not know the future shape of Europe or the world. It is unknown to us what the new international order will look like, what main centres of power will develop, responsible for worldwide harmony, security, and peace. For that very reason the European Union idea, glo- balisation and integration processes have as many supporters as adversaries. What's more, those who until recently were the enthusiasts of globalisation, are saying today, like the Noble laureate Joseph E. Stiglitz, that the way "in which globalisation is conducted, (...) should be thoroughly well-thought-out again". At the same time we observe the renaissance of all kind of nationalisms and attempts to glorify the concept of an ethnic state, as a counterweight to commonwealth and above-national structures. It appears that the ideas that once united Europe, peace and prosperity, are not sufficient today. Unification by further expansion that included Central and Eastern European countries was a great political project, meant to effectively pull together European populace. However, the present Lisbon Treaty confusion is a proof that that project wasn't entirely successful. For the lack of European ideal or broad political plans, national egoism dominated over European interests and 
Commonwealth solidarity. The conflict over the future political shape of the European Union, Europe and the world intensifies. The same concerns free trade as well as such sensitive issues as labour force migration, liberalization of services or reform of the pension and life insurance sectors. That dispute is partly ideological, but also concerns money. Some social groups lose through globalisation and integration, while other gain. Although globalisation through its nature concerns internal players, it holds direct implications for individual member states. To give an example, an aversion to immigration from Africa or Asia is often vented on the immigrants from Poland. The dispute on globalisation doesn't run on the state-to state axis, but the social and cultural lines. In the countries of Western Europe we have many followers and opponents of globalisation. The supporters are as a general rule more wealthy and educated than opponents of globalisation. Whereas migrations are looked at as an advantage from the economic point of view, in the cultural context they are perceived negatively.

It turns out today that one cannot control globalisation by means of traditional political mechanisms, which has an enormous influence on the development of democracy in individual EU member states, as well as the entire Union. The European Union suffers from lack of intermediate democracy, which makes legitimisation of Union policy difficult. Deficiency of democracy in EU is mentioned all the time. What is more, the whole essence of integration is increasingly loudly questioned by scores of politicians, journalists and business executives. President
Nicolas Sarkozy, among others, warned on $11^{\text {th }}$ July 2008 in the European Parliament, that supporters of the Lisbon Treaty will continue to integrate, even without the Treaty and regardless of such sceptics like Ireland, the Czech Republic or Poland. It is an announcement of the return to the concept of "Europe of two-speeds", namely Europe consisting of countries cooperating with each other, and those remaining beyond the integration. If it comes to that, it will be the beginning of the end of the European Union, or at least a definite slow-down of European integration for years to come.

Public opinion polls also show the decrease of the general public support for European integration, especially in the larger Union countries, such as Great Britain, France or Germany. Resistance is felt towards the policy of EU expansion and assimilation. Questions remain unanswered about the EU role in the progressively more globalised world, such as whether European policy should have a global range, or merely regional. How the EU policy on European and world issues ought to be managed and should the Union foreign policy require greater centralisation of the decisive processes? If so, should it be necessary to limit sovereign actions of member states in the most vital matters concerning the Union?

To all the questions mentioned above and many others, concerning the future of the $\mathrm{EU}$ in the steadily more globalised world, an Oxford political scientist Jan Zielonka attempts to find the answers, and he does that in his reviewed, strongly polemical book. The author tries to portray the essence of the transformations in Europe after 1989 and 
their influence on the genesis of the EU and its evolution. He puts forward numerous controversial, but at the same time interesting theses. Among others, he claims that a chance to overcome the Union crisis lies not in the construction of the Union according to the blueprint of a federal state, but as a neo-medieval model with liberal border regime and an overlapping institutions system. According to him, the present $\mathrm{EU}$ contains many attributes distantly departing from the long-held theory of integration. The Union is by itself an economically and politically driven empire and understanding its essence, according to the author, is a task of immense importance. Above that, Jan Zielonka considers that further widening of the European Union is inevitable and should include not only Turkey, but Ukraine as well. By the way, such views are convergent with the principles of Poland's present integration policy, in particular in relation to Union's Eastern Europe strategy.

In the introduction of the reviewed work Jan Zielonka underlines: "I deal with several subjects and issues, from politics and economics to international matters and security problems. The publication contains numerous theoretical discourses and presents an interesting empirical research end results. The reader should find in it an analysis of both Eastern and Western European situations. I try to discuss the problems facing European Union in a way that is unconventional and innovative" (pages V-VI).

The reviewed work is written in a problem subject order. It consists of an extensive and attention-grabbing introduction, six chapters divided into sub-chapters, an interesting and broad conclusion, as well as bibliography, consisting mostly of Anglo-Saxon literature and mentions merely one source that appeared in Polish. It is a pity that the author disregarded Polish research writings on the subject, as they aren't any less valuable and interesting than the Western publications.

In the first three chapters Jan Zielonka talks about the effects of the EU enlargement in 2004, that included the post-communist countries in Central and Eastern Europe. He considers whether that enlargement influenced the character of the Union, and if so, in what way. In the opening chapter, entitled "Return to Europe", the author points to the distance that divided the new member states from the "old 15" at the moment of enlargement, as well as how extensive were the development spans and in which fields they were particularly noticeable. He also attempts to show in what degree the internal reforms, undertaken by individual post-communist states, brought the needed effects and allowed them to adjust for cooperation with the "old 15 " countries. In the conclusion of this chapter Jan Zielonka stresses that: "Since the fall of communism, eight countries that joined the Union (plus Rumania and Bulgaria), have made enormous progress in all the fields considered here. That situation, not at all so obvious in the first decade since the breakthrough, encouraged the EU to take the new democracies seriously. (...). The enlarged European Union will be open, diverse, pluralistic and polycentric. It will rather bring to mind a neo-medieval empire than a superstate of the Westphalian type. Such an empire will however be relatively democratised, with a stable economy and lasting security system" 
(page 57). In this piece of writing it is one of many controversial hypotheses of the author, or a debatable one at least.

In the second chapter of the reviewed work, the author analyses "the influence of the enlargement of the European Union on the waning of the old division between East and West", as well as puts forward another hypothesis, that "the expansion to the East was an impressive example of empire building. The Union attempted to take political and economical control over its unstable and poor neighbours. The operation lacked a wider strategic vision, besides that it exposed susceptibility to particular pressures and its implementation was rather ambiguous. In consequence, Eastern European countries had to succumb to the ever increasing list of conditions, but at the end of the accession process they however got the right to participate in the decision making and received access to the Union money" (page 27). If we accept that theory as true, than in my opinion here also we should search for the rising disenchantment and Euro-scepticism among the "old 15" countries, as well as reluctance to further European Union enlargement. Post-communist Central and Eastern Europe reluctantly surrenders itself to political and economical control and doesn't want to be the peripheral of the neomedieval empire.

In the third chapter Jan Zielonka analyses the progression of mutual adaptation of the two sides of Europe after the fall of real socialism and attempts to illustrate the role and meaning of the development differences in the European integration process. $\mathrm{He}$ states that "Union will find it difficult to adopt the basic features of Westphalian state due to permanent differences between geographical and cultural regions" (page 27). However, in the following chapters, devoted to the analysis of the function of enlarged Europe in the sphere of economics, internal politics and foreign affairs, Jan Zielonka argues that the Union evolves in the direction of "a typical Westphalian state" (page 28).

In the forth and fifths chapters of the reviewed work Jan Zielonka concludes, that in the economic and political sphere the Union heads "rather towards the neo-medieval model" (page 28). I do not know why the author tries at all cost to prove those farfetched arguments, as he himself has certain doubts about their validity. In the writings on the subject, Anglo-Saxon as well, to which he has refered to for many years, the dominant thesis is that the European Union is a hybrid in itself, namely, that it is neither a state nor a classical international organisation and it shall never become such. It will remain, as till now, an unequivocal player in international relations.

The subject of the last, sixth chapter of the presented work deals with different aspects of the internal relations in Europe. Here the author argues, that on the international arena the Union is not at all an entity of the Westphalian type, because its foreign and security policy remain in the hands of member states and not the Union. That's not all, the member countries adopt often entirely different stands and in their foreign and defence policy eagerly make use of all kind of outerEuropean mechanisms. According to the author, the international system shaping in Europe today resembles more the medieval 
order, rather than Westphalian, but he adds that the neo-medieval scenario is not in the least the consequence of the abandonment of CFSP/ESDP plans, but it only supposes the existence of many power centres in the sphere of foreign policy and security matters" (pages 188-189).

One is obliged to make it clear, that the typical "Westphalian state" is a completely different international entity than today's EU. It is a political entity, that has defined boundaries and a government exercising rule over distinct territory, one that has the right to use force, by means of an army or the police. The nature or foundation of a truly Westphalian state is the concept of full sovereignty. However, EU is not entirely a sovereign entity within its territory, and its boundaries undergo continuous changes. It also doesn't have other attributes, common to sovereign countries, such as armed forces and the police, while its international objectives differ from the goals typical for Westphalian states. As Jan Zielonka writes, the European Union “(...) always shows greater interest in the export of its goods, laws and norms, than in imposing direct rule to its neighbours. In this way it also differs from Westphalian states, particularly those that existed after the $18^{\text {th }}$ century" (page 190).

The comprehensive ending, entitled "Conclusions: the Consequences of Neo-medieval Period", should also be considered as one of the most interesting parts of the work. The author once again defends his vision of the European Union as a "neo-medieval empire". He rejects the arguments of his opponents, namely the supporters of EU transformation into a modern European state, who believe that the acceptance of the neo-medieval scenario will mean the end for the European integration process, causing conflicts and chaos" (page 254). He further underlines: "Perhaps they are right, but it is too early to talk about it. Such international bodies like the EU do not fall in an instance. (...) Since 1989 the Union found itself under unusual pressure, but the most frequently proposed formulas probably won't improve its function. So I attempted to show, that the best way to meet the present challenges, would be to adapt to the neo-medieval conditions, by gradual broadening of the plurilateral governments system. (...) I tried to prove, that the neo-medieval empire has a chance to deal with the globalisation pressures, thanks to its natural elasticity and ability to learn. I also made an effort to show that such an empire may be able to compete with the United States and other major powers, because it mobilises wealthy European resources, without giving up the strongest asset Europe has - pluralism and diversity. Further I wished to prove, that a neo-medieval empire may successfully prevent conflicts in its neighbourhood, because it is able to shape the behaviour of different entities by stipulating the EU membership conditions. It also has all predispositions to gain approval of its citizens, as it tries to familiarise them with the ruling structures and encourages rather than punishes. (...) Time came to notice, accept and make use of neomedieval realities" (page 225).

I myself would be more reluctant in formulating such unconditional qualities of neomedieval model for Europe, that Jan Zielonka promotes in the reviewed work, especially as 
in the perception of Europeans "empires" have a bad connotation. Above that, as the history of Europe reminds us, empires were the source of numerous crises, conflicts and wars in Europe.

In conclusion, I would like to emphasise that Jan Zielonka's book deserves a careful reading, not only by academics, but politicians as well. It is a valuable contribution to the European and world discourse on theoretical integration models and new international order scenario. By the way, unfortunately in Poland academic discus- sions on those problems are still in their infancy, which isn't without implication for our present foreign policy. Although there is a consensus that Poland should be in the EU and the NATO, it still hasn't been determined clearly what our expectations of the membership really are and what in practice they actually mean. After 2004, that is once the main aim was achieved, namely Poland's entry into the Euro-Atlantic structures, until now no new strategy has been worked out for our European policy, including the Union and global strategies.

\section{Book review: Human Rights Under Domestic Law, Agnieszka Florczak and Bartosz Bolechow (eds.), Wydawnictwo Adam Marszałek, Toruń 2006, pp. 157}

\section{by Agnieszka Jasińska}

The work entitled "Human Rights Under Domestic Law”, edited by Agnieszka Florczak and Bartosz Bolechow is a joint publication devoted to broadly understood regulations regarding protection of freedom and human rights. The publication is a collection of six articles covering issues in the area of protection of freedom and human rights under domestic law in selected post-communist countries and in the countries of the Commonwealth of Independent States. The book is addressed to students of law, political science, administration and sociology, as well as journalists, officials and all those who want to broaden their knowledge in the field of protection of human rights and freedoms.

The publication begins with a study by a renowned expert in the area, Bogusław
Banaszak, entitled "The Measures of Protection of Human Rights and Freedoms", which presents an extensive comparative spectrum of tools used for protection of human rights and freedoms. The author familiarizes the reader with mechanisms aimed at protection of human rights, with a particular emphasis on constitutional complaint.

An important merit of the part of the publication is the analysis of solutions for protection of human rights and freedoms under domestic law, as compared to Switzerland, Germany and Austria, which enables the reader to have a closer look at the measures of protection of human rights in democratically stable countries.

The next article entitled "The Notion of Human Rights and Freedom Protected by the Constitution" by Robert Kropiwnicki 